2017-08-04

Overwintering individuals of the Arctic

krill Thysanoessa inermis appear

tolerant to short-term exposure to low

$\mathrm{pH}$ conditions

\title{
Venello, TA
}

http://hdl.handle.net/10026.1/10102

10.1007/s00300-017-2194-0

Polar Biology

Springer Science and Business Media LLC

All content in PEARL is protected by copyright law. Author manuscripts are made available in accordance with publisher policies. Please cite only the published version using the details provided on the item record or document. In the absence of an open licence (e.g. Creative Commons), permissions for further reuse of content should be sought from the publisher or author. 
Overwintering individuals of the Arctic krill Thysanoessa inermis appear tolerant to short-term exposure to low $\mathrm{pH}$ conditions

\section{Theresa A. Venello, Piero Calosi, Lucy M. Turner \& Helen S. Findlay}

Polar Biology

ISSN 0722-4060

Polar Biol

DOI 10.1007/s00300-017-2194-0
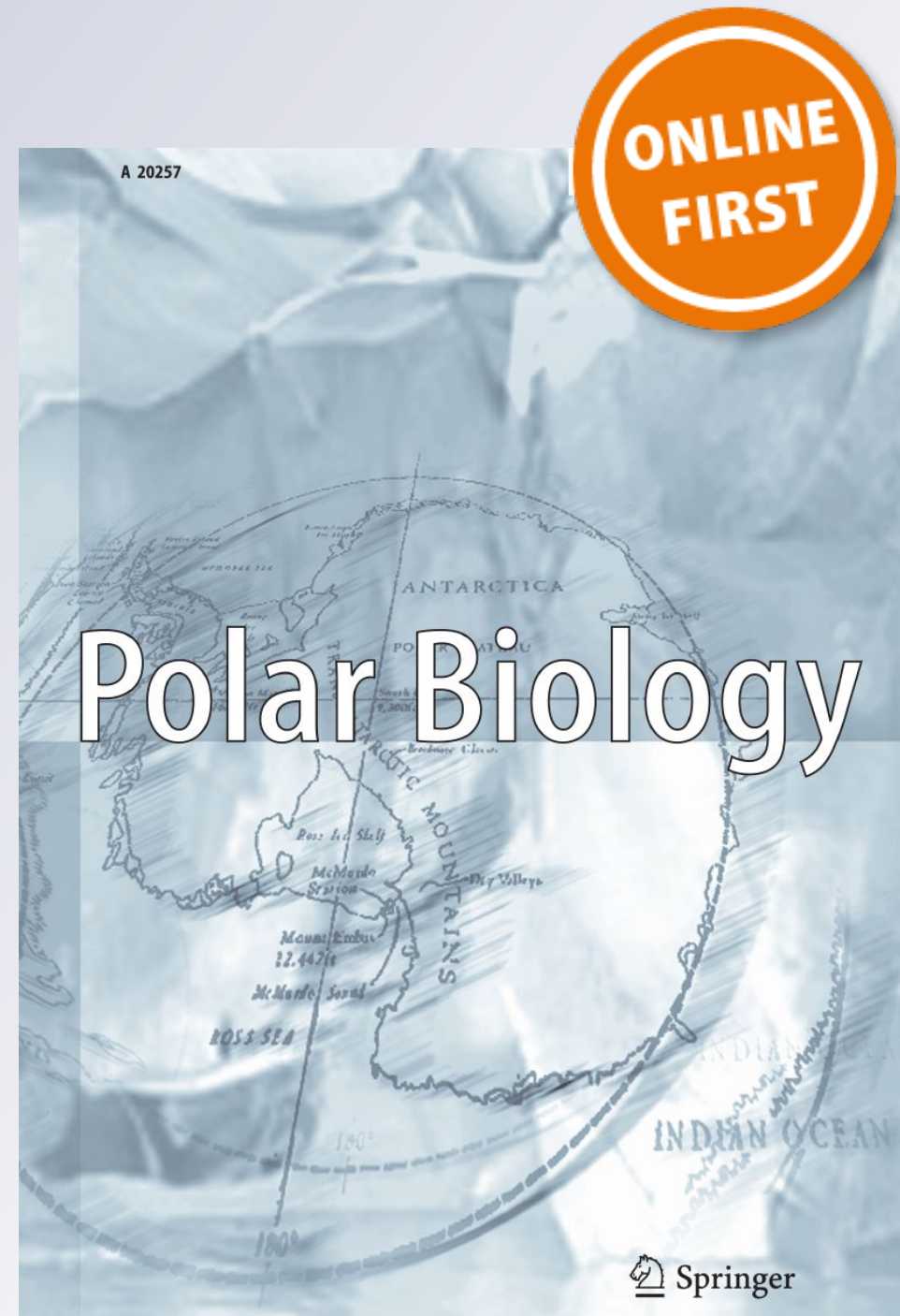

留 Springer 
Your article is protected by copyright and all rights are held exclusively by SpringerVerlag GmbH Germany. This e-offprint is for personal use only and shall not be selfarchived in electronic repositories. If you wish to self-archive your article, please use the accepted manuscript version for posting on your own website. You may further deposit the accepted manuscript version in any repository, provided it is only made publicly available 12 months after official publication or later and provided acknowledgement is given to the original source of publication and a link is inserted to the published article on Springer's website. The link must be accompanied by the following text: "The final publication is available at link.springer.com". 


\title{
Overwintering individuals of the Arctic krill Thysanoessa inermis appear tolerant to short-term exposure to low $\mathrm{pH}$ conditions
}

\author{
Theresa A. Venello ${ }^{1,2,4} \cdot$ Piero Calosi $^{2,3} \cdot$ Lucy M. Turner $^{2} \cdot$ Helen S. Findlay ${ }^{1}$
}

Received: 10 December 2016/Revised: 26 July 2017/ Accepted: 28 July 2017

(C) Springer-Verlag GmbH Germany 2017

\begin{abstract}
Areas of the Arctic Ocean are already experiencing seasonal variation in low $\mathrm{pH} /$ elevated $p \mathrm{CO}_{2}$ and are predicted to be the most affected by future ocean acidification (OA). Krill play a fundamental ecological role within Arctic ecosystems, serving as a vital link in the transfer of energy from phytoplankton to higher trophic levels. However, little is known of the chemical habitat occupied by Arctic invertebrate species, and of their responses to changes in seawater $\mathrm{pH}$. Therefore, understanding krill's responses to low $\mathrm{pH}$ conditions has important implications for the prediction of how Arctic marine communities may respond to future ocean change. Here, we present natural seawater carbonate chemistry conditions found in the late polar winter (April) in Kongsfjord, Svalbard $\left(79^{\circ}\right.$ North) as well as the response of the Arctic krill, Thysanoessa inermis, exposed to a range of low $\mathrm{pH}$ conditions. Standard metabolic rate (measured as oxygen consumption) and energy metabolism markers
\end{abstract}

Electronic supplementary material The online version of this article (doi:10.1007/s00300-017-2194-0) contains supplementary material, which is available to authorized users.

Theresa A. Venello

venellot@gmail.com

1 Plymouth Marine Laboratory, Prospect Place, West Hoe, Plymouth PL1 3DH, UK

2 Marine Biology and Ecology Research Centre, School of Marine Science and Engineering, Plymouth University, Drake Circus, Plymouth, Devon PL4 8AA, UK

3 Département de Biologie, Chimie et Géographie, Université du Québec à Rimouski, 300 Allée des Ursulines, Rimouski, QC G5L 3A1, Canada

4 Present Address: School of Earth and Ocean Sciences, Bob Wright Centre, University of Victoria, Victoria, BC V8W 3V6, Canada (incl. adenosine triphosphate (ATP) and L-lactate) of $T$. inermis were examined. We show that after a 7 days experiment with $T$. inermis, no significant effects of low $\mathrm{pH}$ on $\mathrm{MO}_{2}$, ATP and L-lactate were observed. Additionally, we report carbonate chemistry from within Kongsfjord, which showed that the more stratified inner fjord had lower total alkalinity, higher dissolved inorganic carbon, $p \mathrm{CO}_{2}$ and lower $\mathrm{pH}$ than the well-mixed outer fjord. Consequently, our results suggest that overwintering individuals of $T$. inermis may possess sufficient ability to tolerate short-term low $\mathrm{pH}$ conditions due to their migratory behaviour, which exposes $T$. inermis to the naturally varying carbonate chemistry observed within Kongsfjord, potentially allowing $T$. inermis to tolerate future $\mathrm{OA}$ scenarios.

Keywords Euphausiacea · Arctic Ocean · Kongsfjord · Ocean acidification $\cdot$ Ocean change $\cdot$ Crustaceans

\section{Introduction}

Specific ocean regions have been highlighted as high priority areas for research, as these are predicted to experience a widespread undersaturation of $\mathrm{CaCO}_{3}$, low $\mathrm{pH}$ and elevated $p \mathrm{CO}_{2}$ by mid-twenty-first century (Fabry et al. 2008; Steinacher et al. 2009). One such area of concern is the Arctic Ocean, where the largest change in $\mathrm{pH}(0.3-0.5$ units) is expected to occur (Steinacher et al. 2009) and seasonal undersaturation of aragonite $(\Omega$ aragonite $=<0.7-1)$ with subsequent low $\mathrm{pH}$ and high $p \mathrm{CO}_{2}$ has been documented (Bates et al. 2009). Shelf regions of the Arctic are susceptible to changes in oceanic and atmospheric conditions, typically through the variation in Atlantic water intrusion and glacial meltwater (Cottier 
et al. 2005). Fjords are considered the link between ocean and land via cross-shelf exchange with fjord dynamics seen to actively respond to variation in these conditions. Thus, the properties of water masses in Arctic fjords, especially along the west coast of Svalbard make the area a particularly good indicator of change (Cottier et al. 2005). The Arctic fjord of Kongsfjord in West Svalbard (Norway) is a region that experiences seasonal variations in dominant water masses (Cottier et al. 2005). The fjord is influenced by Arctic and Atlantic currents, while receiving large amounts of freshwater from melting glaciers in the summer (Hop et al. 2002; Cottier et al. 2005; Buchholz et al. 2010). This combination of different water masses creates seasonal gradients of temperature, salinity and density both vertically and horizontally throughout the fjord (Weslawski et al. 2000; Hop et al. 2002; Cottier et al. 2005).

Despite the fact that Kongsfjord has been the site of many ocean acidification (OA) laboratory and mesocosm investigations (Findlay et al. 2010; Lischka and Riebesell 2012; Niehoff et al. 2013; Riebesell et al. 2013), there are limited studies that combine observations of natural conditions in seawater chemistry within the fjord, particularly $p \mathrm{CO}_{2}$ and $\mathrm{pH}$, and relate these to an organism's response to natural variation in $\mathrm{pH} / \mathrm{pCO}$ and future conditions (Fabry et al. 2009; Comeau et al. 2012; Aguilera et al. 2013; Lewis et al. 2013). As Kongsfjord experiences variations in water mass properties, animals within the pelagic realm are more likely to experience a range of seawater conditions (Hop et al. 2002; Buchholz et al. 2010; Comeau et al. 2012). In fact, $\mathrm{pH}$ at depth $(200-300 \mathrm{~m})$ in Kongsfjord has been recorded to range between 8.13 and 7.68, fluctuating over a monthly period (Lischka and Riebesell 2012). Additionally, the vast majority of Arctic low $\mathrm{pH} /$ elevated $p \mathrm{CO}_{2}$ studies have been carried out in summer, and therefore April (polar spring) OA studies using overwintering organisms in the Arctic are rare. Overwintering organisms may be particularly sensitive to environmental changes, as low food availability may increase their sensitivity to stress (Comeau et al. 2012; Lischka and Riebesell 2012; Lewis et al. 2013).

Krill are one of the most abundant first order consumers in Arctic ecosystems (Falk-Petersen et al. 2000; Hop et al. 2002). As a dominant member of the zooplankton community, krill play a vital role in the transfer of energy between primary producers and higher trophic levels (Hop et al. 2002). High lipid content and abundance make krill an important prey item for fish, sea birds and marine mammals in the Arctic (Hop et al. 2002; Dahl et al. 2003). In addition to their role in the Arctic food web, euphausid species have been used as indicators of advection and warming in Kongsfjord and are considered good indicators of change due to their mid-trophic level position (Buchholz et al. 2010). Therefore, understanding krill responses to OA is essential for predicting the future of Arctic ecosystems. The Kongsfjord zooplankton including krill, experience variations in seawater chemistry on a daily and seasonal basis due to changes in water mass dominance and migratory behaviour (Weslawski et al. 2000; Buchholz et al. 2010; Agersted et al. 2011). Large aggregations of krill, possibly due to hydrological forces such as estuarine circulation patterns, have been found in Kongsfjord at the glacier fronts during Arctic summer, June-August (Weslawski et al. 1994, 2000; Hop et al. 2002). Here, meltwater can significantly lower the $\mathrm{pH}$ of the seawater as a result of dilution (Azetsu-Scott et al. 2010).

In general, crustaceans should be more tolerant to ocean acidification due to the fact that they inhabit areas with fluctuating environmental conditions; however, to date physiological studies have shown that polar species may struggle to compensate for changes set by low $\mathrm{pH}$ (Whiteley 2011; Thor and Dupont 2015; Bailey et al. 2017). Due to the potential tolerance level of crustaceans, it is necessary to understand organism behaviour, life history and ecology in relation to the environmental conditions in which they live to assess possible sensitivity in a changing Arctic ecosystem. Zooplankton, in particular those with migratory behaviours, may have evolved to withstand predicted Arctic conditions based on their exposure to a range of $p \mathrm{CO}_{2} / \mathrm{pH}$ conditions on a daily basis (Lewis et al. 2013), however, very few studies address both the natural and predicted future $\mathrm{pH}$ conditions when looking at organism response.

Previous works have suggested that species and populations living in elevated $p \mathrm{CO}_{2}$ habitats ( e.g. deep-sea, $\mathrm{CO}_{2}$ vents, upwelling zones) are more tolerant to elevated $p \mathrm{CO}_{2}$ conditions ( $\left.>900 \mu \mathrm{atm}\right)$ than their counterparts living in habitats with lower $p \mathrm{CO}_{2}$ (Maas et al. 2012; Calosi et al. 2013b; Pespeni et al. 2013). In particular, deep-sea copepods from the subarctic North Pacific were found to have a higher tolerance to mortality in high $p \mathrm{CO}_{2}$ conditions than shallow living sub-tropical copepods (Watanabe et al. 2006). Vertically migrating Arctic copepods have been shown to experience a range of $p \mathrm{CO}_{2}$ conditions ( $>140 \mu \mathrm{atm})$ as they make daily movements, with a minimum $p \mathrm{CO}_{2}$ of $240 \mu \mathrm{atm}$ in the surface waters and maximum $p \mathrm{CO}_{2}(564.2 \mu \mathrm{atm})$ at depth (Lewis et al. 2013). Due to this movement and exposure to varying $p \mathrm{CO}_{2}$ conditions, elevated $p \mathrm{CO}_{2}$ (700 and $\left.1000 \mu \mathrm{atm}\right)$ had no significant effect on the mortality of adults of the copepods Calanus glacialis and Calanus hyperboreus in the high Canadian Arctic. In contrast, surface water dwelling adult copepods of Oithona similis experienced significant increases in mortality due to elevated $p \mathrm{CO}_{2}$ as they are exposed to a smaller range of $p \mathrm{CO}_{2}$ conditions $(<75 \mu \mathrm{atm})$ and vertical migrations are minimal in this species (Lewis et al. 2013). 
As a pelagic species that exhibits migratory behaviour, Arctic krill Thysanoessa inermis, is one of the most important zooplankton within Kongsfjord (Hop et al. 2006) and has a life span of three to four years in the Arctic with spawning taking place just after the start of the spring bloom (Falk-Petersen et al. 2000). Due to shortages of food availability in the winter months, krill have adapted to store large amounts of lipids as wax esters and triacylglycerols, taking advantage of the short intense periods of primary productivity to rapidly increase in weight from March to May (Sargent and Falk-Petersen 1981; Falk-Petersen et al. 2000). The large lipid reserves are enough to sustain body function in $T$. inermis throughout the winter with no food intake, with lipid stores reserved for either spring growth or reproduction (Sargent and Falk-Petersen 1981).

In spite of being an integral part of Arctic ecosystems, very little is known about krill responses to low $\mathrm{pH} / \mathrm{ele}$ vated $p \mathrm{CO}_{2}$ conditions with most studies centred on Antarctic and Northern Atlantic krill species. Moreover, most krill investigations related to OA have focused on egg hatching, development and mortality. A study on the physiological responses of the Antarctic krill, Euphausia superba, to elevated $p \mathrm{CO}_{2}$ showed an increase in ingestion rates, nutrient release rates and metabolic enzyme activity at $750 \mu \mathrm{atm}$ (Saba et al. 2012). Kawaguchi et al. (2013) demonstrated that $E$. superba hatching rates were significantly affected at 1250 and $1500 \mu \mathrm{atm}$ of $p \mathrm{CO}_{2}$ and no hatching occurred at 1750 and $2000 \mu$ atm $p \mathrm{CO}_{2}$. In addition, development of $E$. superba was shown to be severely inhibited before gastrulation at $2000 \mu \mathrm{atm}$, though the krill appear to be able to develop normally up to $1000 \mu \mathrm{atm}$, possibly as the result of adaptation to low $\mathrm{pH} /$ elevated $p \mathrm{CO}_{2}$ conditions found in the natural environment (Kawaguchi et al. 2011).

A physiological and biochemical approach is necessary to further our understanding of organism response to environmental change (Pörtner et al. 1999; Somero 2002). Evidence of physiological tolerance to low $\mathrm{pH} / \mathrm{elevated}$ $p \mathrm{CO}_{2}$ based on exposure to environmental gradients has been observed in oxygen minimum zones. Shelled pteropods are considered to be particularly sensitive to OA due to their aragonite shells. However, metabolic rates and ammonia excretion, as indicators of physiological response, were measured in pteropod species after exposure to low $\mathrm{pH} / \mathrm{elevated} \mathrm{CO}_{2}(1000 \mu \mathrm{atm})$ (Maas et al. 2012). Hyalocylis striata, Clio pyramidata, Cavolinia longirostris and Creseis virgule migrate naturally into oxygen minimum zones with high $\mathrm{pCO}_{2}$ and showed no effect of low $\mathrm{pH} /$ elevated $p \mathrm{CO}_{2}$ (Maas et al. 2012). Conversely, low $\mathrm{pH} /$ elevated $p \mathrm{CO}_{2}$ and temperature negatively affected whole organism and cellular physiology of Littorina littorea when considering complex responses to environmental change such as metabolic rates, adenylate energy nucleotide concentrations and end-product metabolite concentrations (Melatunan et al. 2011).

This study aims to investigate whole organism and cellular physiological responses to exposure to low $\mathrm{pH} /$ elevated $p \mathrm{CO}_{2}$ of overwintering individuals of an understudied, yet ecologically important Arctic krill species from a fjord environment that would be expected to have naturally variable carbonate chemistry. There has been no investigation to date, where an integrated whole and cellular organism level approach (i.e. the characterization of metabolic rates in addition to cellular aerobic and anaerobic metabolite accumulation) has been used to examine Arctic krill under low $\mathrm{pH} /$ elevated $\mathrm{pCO}_{2}$ conditions. By investigating overwintering $T$. inermis' short-term biological responses to low $\mathrm{pH} /$ elevated $\mathrm{pCO}_{2}$ conditions we hypothesise that krill may be able to withstand short-term changes in $\mathrm{pH}$ due to their migratory behaviour and preexposure to a range of $\mathrm{pH}$ conditions. This study provides insight into the future of krill in Arctic ecosystems during a potentially vulnerable stage of their life history.

\section{Methods}

\section{Study area and field work}

Kongsfjord is located on the west coast of Spitsbergen, Svalbard, Norway $79^{\circ} \mathrm{N}, 12^{\circ} \mathrm{E}$ (Fig. 1). It is an open Arctic fjord that is approximately $30 \mathrm{~km}$ long and $10 \mathrm{~km}$ wide, with depths in some areas reaching $>300 \mathrm{~m}$. Krill were collected from the centremost area of Kongsfjord $\left(78^{\circ} 56^{\prime} 963 \mathrm{~N}, 12^{\circ} 02^{\prime} 358 \mathrm{E}\right)$ on April 22, 2014 using the Kings Bay boat, Tiesten. Mesopelagic trawls were conducted for 30 min using a 200- $\mu \mathrm{m}$ WP2 zooplankton net, travelling an average speed of 1.5 knots. The net was

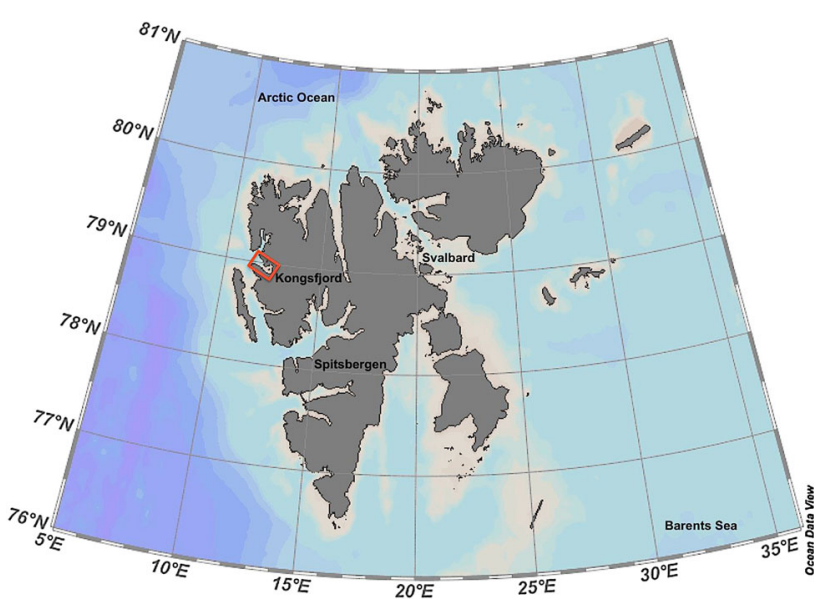

Fig. 1 The red box highlights the location of Kongsfjord on the west coast of Spitsbergen, Svalbard, Norway $79^{\circ} \mathrm{N}, 12^{\circ} \mathrm{E}$. Map was created using Ocean Data View 4.6.2. (Color figure online) 
trawled horizontally in depths ranging from 60 to $200 \mathrm{~m}$. Krill were collected at depth $\left(1.6 \pm 0.03{ }^{\circ} \mathrm{C}\right)$, carefully and quickly removed from the net then transferred to sealed buckets containing seawater. Once back in Ny-Ålesund, the krill were transferred to a holding tank for one day to acclimatise to the laboratory setting then distributed randomly to the experimental tanks, where they were left for another day in ambient conditions (temperature $3.0 \pm 0.2{ }^{\circ} \mathrm{C}, \mathrm{pH}_{\text {total }} 8.03 \pm 0.005$, dissolved oxygen $105.7 \pm 0.3 \%$, salinity $35 \pm 0.0$ ) before $\mathrm{CO}_{2}$ bubbling was started. The water in both the holding and experimental tanks was continuously pumped into the laboratory from the middle of Kongsfjord at $80 \mathrm{~m}$ depth. During this time, a sub-sample of the krill was taken for identification purposes. Krill were identified as adult individuals of $T$. inermis (3.1-61.3 $\mathrm{mg} \mathrm{WW}$ ), as abdominal spines were present, according to Boden et al. (1955), Nemoto (1966), Mauchline (1980) and Kathman et al. (1986). Water samples were collected on board the Kings Bay boat, Tiesten, on April 25th, 2014 at five stations throughout the fjord (Online Resource 1) for determining the natural conditions that the krill were experiencing at the time of the experiment. Conductivity, temperature and depth were recorded using a SAIV A/S CTD (Model SD204, Bergen, Norway) to create a profile of the water column at each station. 10-L Niskin bottles were lowered to depths ranging from the surface to $300 \mathrm{~m}$ (Online Resource 1) for water sample collection for total alkalinity (TA) and dissolved inorganic carbon (DIC) measurements. Water samples were stored in $50-\mathrm{mL}$ glass bottles and treated with $20 \mu \mathrm{L}$ of mercuric chloride $\left(\mathrm{HgCl}_{2}\right)$ for preservation for future analysis following standard protocols of Dickson et al. (2007).

\section{Ocean acidification experiment}

The seven-day laboratory experiment used a range of $\mathrm{pH}$ (four) conditions as suggested by Dupont and Pörtner (2013), similar to the approach used by Christen et al. (2013) to cover both present and future levels of seawater $\mathrm{pH}$ and $p \mathrm{CO}_{2}$ in order to acquire a greater predictive ability on $\mathrm{pH}$-dependent responses. The chosen range also follows future scenarios predicted for the Arctic Ocean as a decrease by $0.3-0.5 \mathrm{pH}$ units could occur over the next century (Caldeira and Wickett 2003). The target $\mathrm{pH}$ levels (total scale, $\mathrm{pH}_{\text {total }}$, calculated in CO2SYS version 2.1, Lewis and Wallace 1998) for the experiment were a control $\mathrm{pH}_{\text {total }}$ of 8.00 as this was the ambient $\mathrm{pH}$ of the fjord water that was pumped into the Kings Bay Laboratory; and target treatment levels of 7.75, 7.65 and 7.35 (equivalent to $p \mathrm{CO}_{2}$ levels of 750, 1000 and $2000 \mu \mathrm{atm}$, respectively), mimicking both fjord conditions and future scenarios. The second lowest target $\mathrm{pH}$ of $7.65\left(1000 \mu \mathrm{atm} p \mathrm{CO}_{2}\right)$ is reflective of winter conditions within Kongsfjord (Lischka and Riebesell 2012), while the lowest $\mathrm{pH}$ treatment of 7.35 was chosen as a future value not presently observed within Kongsfjord, in order to test $T$. inermis' response to low $\mathrm{pH}$ beyond what they are currently exposed to. However, note that the measured values were slightly different $(7.96,7.70$, 7.65 and 7.28) from the target $\mathrm{pH}$ values and we used the measured means in further discussion and analysis. Pure $\mathrm{CO}_{2}$ was bubbled into header tanks and regulated by $\mathrm{pH}$ controllers (Aqua Digital pH 201, Precise Instruments, J \& K Aquatics Ltd, North Petherton, UK). Each header tank fed water via black gas impermeable tubing into three replicate 5-L containers with each replicate housing 30 adult krill. Thysanoessa inermis is a known herbivore within Kongsfjord (Falk-Petersen et al. 2000) and diatom Thalassiosira weissflogii has been used as a food source in laboratory settings in previous experiments (Pinchuk and Hopcroft 2006; Dalpadado et al. 2008; Agersted et al. 2011). In the evening, krill were fed approximately 1000 cells $\mathrm{mL}^{-1}(16.7 \mu \mathrm{L}$ per container) of Instant Algae Diatoms, T. weissflogii (Batch \#14053 CCMP 1051/TW sp.) to mimic the amount of food available in the fjord at the time of the experiment (AWIPEV Underwater Observatory, https://cosyna-nodes.shinyapps.io/svl_ferrybox/). Krill were also consistently kept in the dark to mimic natural fjord conditions until data collection were carried out. Temperature, salinity, dissolved oxygen and $\mathrm{pH}$ were recorded using a hand-held probe (SevenGo Pro, MettlerToledo, Columbus, OH, USA) daily in the header tanks and calibrated every other day. Water samples for alkalinity (TA and DIC) were taken from the replicate tanks on the third, sixth and seventh day to limit the number of times tank lids were opened. The water samples were then treated with $20 \mu \mathrm{L}$ of mercuric chloride $\left(\mathrm{HgCl}_{2}\right)$ to preserve for future analysis. $\mathrm{pH}$ was converted to total scale from $\mathrm{pH}$ measured on the NBS scale using CO2SYS (version 2.1, Lewis and Wallace 1998) so as to be compared to fjord $\mathrm{pH}_{\text {total }}$ that was calculated based on TA and DIC analysis.

\section{Seawater chemistry}

Seawater samples collected from the laboratory experiments were analysed for total alkalinity. Total alkalinity was measured by Hydrochloric $(0.08 \mathrm{M})$ acid-titration using a seawater gran titrator (AS-ALK2, Apollo Sci-Tech Inc., Bogart, GA, USA) and a pH bench top metre (ORION 3 STAR, Thermo Fisher Scientific Inc., Waltham, MA, USA). Total alkalinity was measured in the seawater samples in duplicates of $12 \mathrm{~mL}$. Water samples collected from Kongsfjord were analysed for both TA and DIC. Dissolved inorganic carbon was measured using a DIC analyser and $\mathrm{CO}_{2}$ detector (AS-C3 and a LI-COR LI-7000 $\mathrm{CO}_{2} / \mathrm{H}_{2} \mathrm{O}$ Analyzer, Apollo Sci-Tech Inc., Bogart, GA, USA). For both TA and DIC, Certified Reference Materials 
(Dickinson Laboratory, University of California, Batch 137) were used to assess precision. Once values for TA and DIC were recorded, CO2SYS (Lewis and Wallace 1998) version 2.1 was used to calculate the values of $p \mathrm{CO}_{2}$ for the laboratory samples along with $\mathrm{pCO}_{2}$ and $\mathrm{pH}$ for the fjord seawater samples. The constants used for CO2SYS were from Mehrbach et al. (1973) (refitted by Dickson and Millero 1987). Water column profiles of temperature and salinity in Kongsfjord were constructed using SAIV A/S CTD (Model SD204, Bergen, Norway) data along with measured TA, DIC and calculated $\mathrm{pH}, p \mathrm{CO}_{2}$ in Ocean Data View (Version 4.6.2).

\section{Determination of standard metabolic rate}

Oxygen consumption rates $\left(\mathrm{MO}_{2}\right)$ of $T$. inermis were determined at the end of the 7-d exposure period and used as a proxy for standard metabolic rate, following the methods by Melatunan et al. (2011) and Donohue et al. (2012). Due to the small size of the krill, and in order to carry out individual tests, blacked-out screw cap micro-centrifuge tubes $(1.5 \mathrm{~mL})$ were used as respirometry chambers. Centrifuge tubes have been previously used as a gas tight $\left(\mathrm{O}_{2}\right)$ chamber over a 48-h period (Terai et al. 2002). Each tube was filled with double filtered (pore size $0.4 \mu \mathrm{m}$ ) water, to reduce the amount of background respiration within the chambers, taken from each individual krill's designated treatment to maintain the same $\mathrm{pH}$ level. Each filled chamber, while fully submerged, was swabbed with a cotton bud to remove any trapped air bubbles before the krill were placed into the chamber. Krill individuals were gently inserted into the micro-centrifuge tubes using a modified pipette that was cut to make the opening large enough for the krill, and then the tubes were quickly sealed. All these operations were undertaken under water. Once closed, the chambers were placed in a continuous-flow water bath on top of a magnetic stirrer plate. Each chamber contained a magnetic flea $(0.5 \mathrm{~mL})$ under a fine plastic mesh $(0.5 \mathrm{~mL})$ held within each cap of the tube to ensure appropriate mixing of the water, in order to maintain conditions homogeneous within the chamber. The amount of seawater in each chamber was calculated, taking into account the volume of the stirrer, mesh and individual krill using volume displacement. Each $\mathrm{MO}_{2}$ trial (five in total) had 12 krill individuals, one from each container, and three blank chambers to measure background respiration. Oxygen concentration in the chamber $\left(\mu \mathrm{mol} \mathrm{L}{ }^{-1}\right)$ was measured approximately every 4 min during the $15 \mathrm{~min}$ incubation period, following a $10 \mathrm{~min}$ resting period to allow krill to recover from being inserted into the respirometry chambers. The length of incubation was determined by preliminary tests such that the krill did not experience hypoxic conditions $(<80 \%$ saturation) so as to not cause undue stress (Storch et al. 2009). $\mathrm{O}_{2}$ measurements were recorded using an $\mathrm{O}_{2}$ probe with a non-invasive fibre optic cable (Fibox 4 PSt 3, Pre Sens, Regensburg, Germany) that was placed on top of a prefixed oxygen sensor dot (Sensor Spots, Pre Sens) within each chamber. $\mathrm{MO}_{2}$ was calculated using the delta of the $\mathrm{O}_{2}$ level at the beginning and at the end of the incubation trial, minus the background respiration from the blanks. After each trial, krill were removed from the chambers, gently blotted then rapidly weighed; the cephalothorax and abdomen were separated, and individually frozen with liquid nitrogen. The abdomen was preserved for future biochemical assays. The krill were stored in Eppendorf tubes at $-80{ }^{\circ} \mathrm{C}$ in the Kings Bay Marine Lab freezer until the samples were shipped on dry ice to Plymouth University where they were stored again at $-80{ }^{\circ} \mathrm{C}$ until biochemical analyses were carried out.

\section{Biochemical assays}

The abdominal muscles of experimental krill were used for the biochemical assays. The tissue samples were weighed then prepared using 12 parts of $0.9 \mathrm{M}$ perchloric acid to one part tissue sample. After the acid was introduced, the sample was sonicated (Misonix Microson Ultrasonic Cell Disruptor XL 2000, Qsonica LLC, Newtown, CT, USA) for $10 \mathrm{~s}$. The sample solution was then centrifuged (Centrifuge 5418, Eppendorf AG, Hamburg, Germany) in a controlled temperature room $\left(4{ }^{\circ} \mathrm{C}\right.$ ) for $10 \mathrm{~min}$ at $14,000 \mathrm{rpm}$ after which the supernatant was removed and three parts of potassium carbonate $\left(\mathrm{K}_{2} \mathrm{CO}_{3}\right)$ to one part of the tissue sample was added. The supernatant and $\mathrm{K}_{2} \mathrm{CO}_{3}$ solution was again centrifuged for $10 \mathrm{~min}$. The supernatant was removed, placed into a new Eppendorf tube and then stored at $-80{ }^{\circ} \mathrm{C}$ until biochemical analysis was conducted.

ATP concentration was determined using a commercial luciferase reagent kit (BioThema, Handen, Sweden, ATP Kit SL, 144-041). This reagent is a sustained light reagent, where certain concentrations of luciferase and luciferin will lead to an output of light in the presence of ATP, where the rate of light output is proportional to the concentration of ATP present. Derived from the kit instruction sheet, the method uses an internal standard as the rate of light output is dependent on the enzymatic activity of the luciferase which can be affected by several factors in ATP extracts like phosphate (Lundin 2000). Luminescence was measured using a luminometer (Pi-102, Hygiena LLC, Camarillo, CA, USA) using the slope of the reaction where the presence and absence of the internal ATP standard was used to determine ATP concentration.

L-lactate concentration was determined using a commercial kit (Trinity Biotech PLC, Bray, Co Wicklow, Ireland) in a 96-well plate format, using a plate reader (Versa Max Microplate, Molecular Devices Corp., Sunnyvale, 
Table 1 Values (Mean \pm SD) for laboratory seawater chemistry per target $\mathrm{pH}$ treatment: $\mathrm{pH}$ (NBS scale), temperature $\left({ }^{\circ} \mathrm{C}\right)$, salinity and total alkalinity (TA) were measured

\begin{tabular}{llllllll}
\hline Target $\mathrm{pH}$ & $N$ & Measured $\mathrm{pH}(\mathrm{NBS})$ & $\mathrm{pH}_{\text {total }}$ & Temperature $\left({ }^{\circ} \mathrm{C}\right)$ & Salinity & Total alkalinity $\left(\mu \mathrm{mol} \mathrm{kg}^{-1}\right)$ & $p \mathrm{CO}_{2}(\mu \mathrm{atm})$ \\
\hline 8.12 & 9 & $8.06 \pm 0.06^{\mathrm{a}}$ & $7.96 \pm 0.06^{\mathrm{a}}$ & $4.4 \pm 0.2$ & $34.81 \pm 0.0$ & $2386.5 \pm 14.5^{\mathrm{a}}$ & $488.4 \pm 82.2^{\mathrm{a}}$ \\
7.85 & 9 & $7.79 \pm 0.06^{\mathrm{b}}$ & $7.70 \pm 0.07^{\mathrm{b}}$ & $4.6 \pm 0.3$ & $34.81 \pm 0.0$ & $2391.4 \pm 18.4^{\mathrm{a}}$ & $1010.5 \pm 219.6^{\mathrm{b}}$ \\
7.75 & 9 & $7.75 \pm 0.10^{\mathrm{b}}$ & $7.65 \pm 0.10^{\mathrm{b}}$ & $4.5 \pm 0.3$ & $34.81 \pm 0.0$ & $2390.8 \pm 13.7^{\mathrm{a}}$ & $1049.4 \pm 282.8^{\mathrm{b}}$ \\
7.45 & 9 & $7.38 \pm 0.06^{\mathrm{c}}$ & $7.28 \pm 0.06^{\mathrm{c}}$ & $4.5 \pm 0.1$ & $34.81 \pm 0.0$ & $2386.2 \pm 13.0^{\mathrm{a}}$ & $2647.2 \pm 455.7^{\mathrm{c}}$ \\
\hline
\end{tabular}

$\mathrm{pH}_{\text {total }}$ and $p \mathrm{CO}_{2}$ values were calculated using CO2SYS

Superscripts represent differences among $\mathrm{pH}$ treatments based on a fitted line regression and a post hoc Tukey test $(\alpha=0.05)$ : ${ }^{\mathrm{a}, \mathrm{b}, \mathrm{c}} p=0.000$

CA, USA). Concentrations of L-lactate were determined using a standard curve. Absorbance was read at $540 \mathrm{~nm}$.

\section{Statistical analysis}

Lactate data was transformed using $\log _{10}$ to meet the assumptions of normality of distribution and homogeneity of variances while all other parameters $\left(\mathrm{MO}_{2}\right.$ and ATP) met this assumption without transformation. Fitted line regressions were used to investigate the consistency of laboratory seawater chemistry. First, a general linear model (GLM) was run for each biological parameter against $\mathrm{pH}$ treatment as a fixed factor, tank as a random nested variable within a specific $\mathrm{pH}$ treatment and body mass as a covariate to ascertain whether our replicate tanks per treatment had any significant effect on the selected parameters. Tank had no significant effect on krill biology (GLM ANOVA, $\mathrm{MO}_{2}: F(8,25)=1.72, p=0.144$; ATP: $F(8,26)=1.21, \quad p=0.333 ; \quad$ L-lactate: $F(8,15)=0.29$, $p=0.958$ ), and thus this term was removed from subsequent analyses. To account for the difference in krill body mass between treatments, an individual sample approach was used (see Bennett 1987; Calosi et al. 2013c). A GLM was run for each biological parameter $\left(\mathrm{MO}_{2}\right.$, ATP and L-lactate) with $\mathrm{pH} / \mathrm{pCO}_{2}$ treatment as a fixed factor and body mass as a covariate. After which the residuals, the remaining variability not explained by body mass, from the previous analysis were used to investigate the effect of seawater chemistry $\left(\mathrm{pH} / p \mathrm{CO}_{2}\right)$ on the biological parameter using a GLM again, as suggested by Bennett (1987). All statistical analysis was conducted using Minitab 17.

\section{Results}

\section{Seawater chemistry}

\section{Laboratory conditions}

Laboratory seawater $\mathrm{pH}$ conditions were comparable to the target $\mathrm{pH}$ treatment values originally set and were distinct across treatments (Fitted line regression, $F(1,46)=309.53$, $p=0.000$; Table 1). Total alkalinity (TA) measurements from the laboratory samples were consistent across all $\mathrm{pH}$ treatments (Fitted line regression $F(1,46)=0.02$, $p=0.883$; Table 1).

\section{Kongsfjord conditions}

On average, fjord seawater was cooler and slightly fresher $\left(T<-0.56{ }^{\circ} \mathrm{C} ; S<34.81\right)$ in the inner fjord, and warmer and more saline $\left(T>1.72{ }^{\circ} \mathrm{C} ; S>35.13\right)$ in the outer fjord. While the inner fjord waters were more stratified, with temperature (Fig. 2a) and salinity (Fig. 2b) both increasing with depth; the outer fjord was well mixed, with temperature and salinity remaining stable throughout the water column. Total alkalinity (TA) (Fig. 3a) was lowest $\left(<2248.9 \mu \mathrm{mol} \mathrm{kg}{ }^{-1}\right)$ at $30 \mathrm{~m}$ in the inner fjord, while the
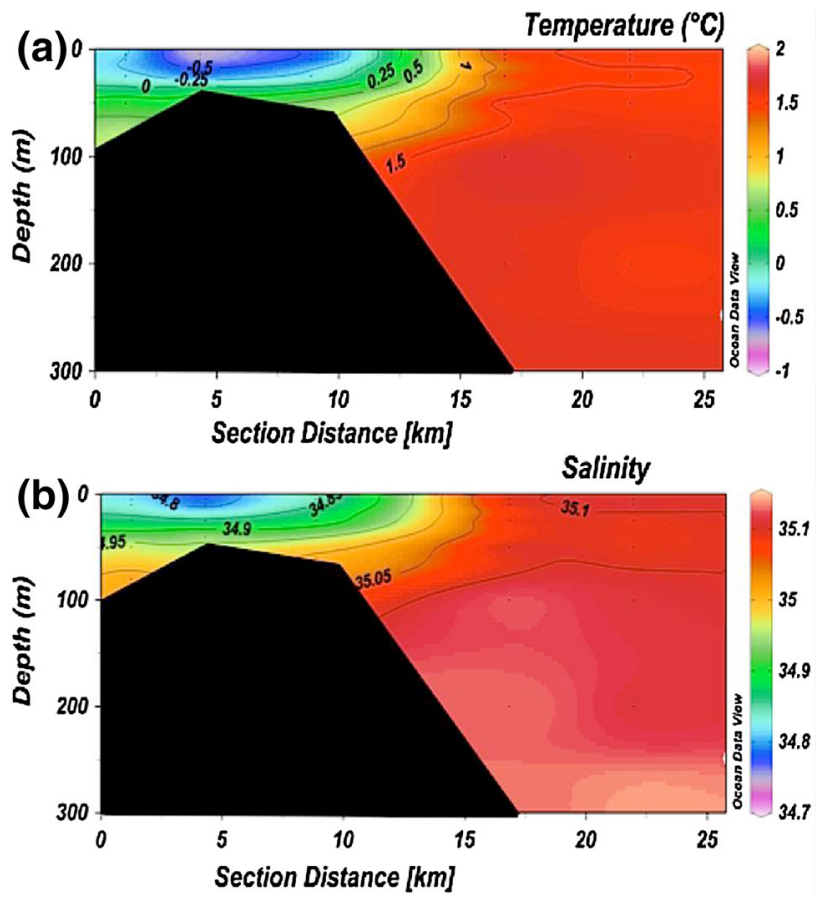

Fig. 2 Kongsfjord water column profiles for all five sampling stations: a Temperature $\left({ }^{\circ} \mathrm{C}\right)$, b Salinity. Water column figures were created using Ocean Data View 4.6.2. (Color figure online) 

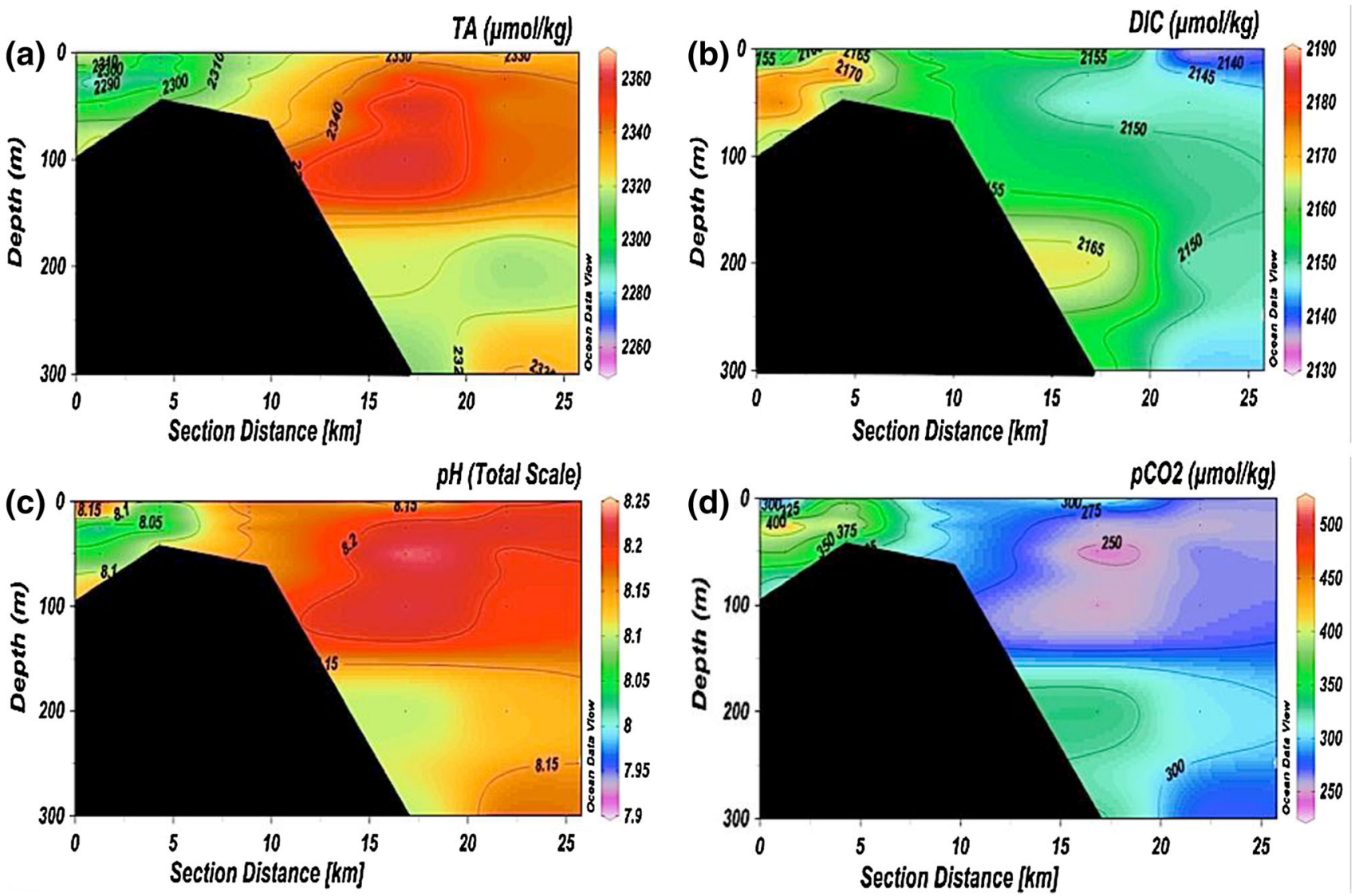

Fig. 3 Kongsfjord water column profiles for all five sampling stations: a Total Alkalinity $\left(\mu \mathrm{mol} \mathrm{kg} \mathrm{kg}^{-1}\right)$, b Dissolved Inorganic Carbon $\left(\mu \mathrm{mol} \mathrm{kg}{ }^{-1}\right)$, c calculated $\mathrm{pH}_{\text {total }}$, $\mathbf{d}$ calculated $p \mathrm{CO}_{2}(\mu \mathrm{atm})$. CO2SYS calculations were preformed using constants from

Mehrbach et al. (1973) refit by Dickson and Millero (1987). Water column figures were created using Ocean Data View 4.6.2. (Color figure online)

Table 2 Values (mean $\pm \mathrm{SD},(N)$ ) for the biological parameters measured in the Arctic krill Thysanoessa inermis at the four different $\mathrm{pH}$ treatments

\begin{tabular}{llllll}
\hline $\mathrm{pH}_{\text {total }}$ & $\mathrm{O}_{2}\left(\mu \mathrm{mol} \mathrm{h}{ }^{-1} \mathrm{~g}^{-1} \mathrm{WW}\right)$ & $\mathrm{O}_{2}\left(\mu \mathrm{mol} \mathrm{h}{ }^{-1} \mathrm{~g}^{-1} \mathrm{DW}^{\mathrm{a}}\right)$ & $\mathrm{ATP}\left(\mu \mathrm{mol} \mathrm{g}{ }^{-1}\right)$ & Lactate $\left(\mathrm{mmol} \mathrm{L}^{-1}\right)$ & Body mass $(\mathrm{g})$ \\
\hline 7.96 & $6.9 \pm 4.8(8)$ & $27.4 \pm 19.3(8)$ & $0.052 \pm 0.037(8)$ & $1.084 \pm 0.276(8)$ & $0.009 \pm 0.003(8)$ \\
7.70 & $4.6 \pm 2.6(12)$ & $18.2 \pm 10.6(12)$ & $0.060 \pm 0.041(12)$ & $0.810 \pm 0.485(7)$ & $0.019 \pm 0.020(12)$ \\
7.65 & $4.1 \pm 2.7(10)$ & $16.2 \pm 10.9(10)$ & $0.037 \pm 0.026(10)$ & $0.708 \pm 0.192(7)$ & $0.010 \pm 0.003(10)$ \\
7.28 & $4.9 \pm 5.1(8)$ & $19.4 \pm 20.3(8)$ & $0.052 \pm 0.039(8)$ & $0.763 \pm 0.673(6)$ & $0.020 \pm 0.018(8)$ \\
\hline
\end{tabular}

${ }^{\text {a }}$ Dry weight was assumed to be $25 \%$ of the wet weight as per Saborowski et al. (2002)

outer fjord was divided with an area of high TA $\left(>2341.0 \mu \mathrm{mol} \mathrm{kg}^{-1}\right.$ ) from the surface down to $150 \mathrm{~m}$, after which the TA decreased. Dissolved inorganic carbon (DIC) (Fig. 3b) was highest $\left(>2172.4 \mu \mathrm{mol} \mathrm{kg}{ }^{-1}\right.$ ) in an area between $10-80 \mathrm{~m}$ in the inner fjord, while the outer fjord was more stratified but had overall lower DIC. $\mathrm{pH}$ was lowest $\left(\mathrm{pH}_{\text {total }}<8.0\right)$ between 10 and $80 \mathrm{~m}$ in the inner fjord, while the outer fjord was distinctly divided, with highest $\mathrm{pH}\left(\mathrm{pH}_{\text {total }}>8.2\right)$ found from the surface to $150 \mathrm{~m}$, after which $\mathrm{pH}$ decreased with depth (Fig. 3c). $p \mathrm{CO}_{2}$ was highest $(>404.9 \mu \mathrm{atm})$ at $30 \mathrm{~m}$ in the inner fjord with more stratified waters, while the outer fjord had two distinct areas where $p \mathrm{CO}_{2}$ was lowest $(<268.6 \mu \mathrm{atm})$ down to $150 \mathrm{~m}$, then increased with depth (Fig. 3d).

\section{Krill physiological responses}

Seawater $\mathrm{pH}$ had no significant effect on the residual of the biological parameters versus individuals' body mass, i.e. the remaining unexplained variability in the biological parameter after accounting for body mass, of $\mathrm{MO}_{2}$, ATP and $\log _{10}$-lactate (Tables 2, 3). Krill survival averaged 
Table 3 Summary of the statistical results for the general linear models of the residual of the biological parameters versus individuals body mass, i.e. the remaining unexplained variability in the biological parameter after accounting for body mass

\begin{tabular}{lllll}
\hline Biological parameter & df & Adj. MS & $F$ & $p$ \\
\hline Residual $\mathrm{MO}_{2}$ & 3 & 0.000013 & 0.02 & 0.995 \\
Residual ATP & 3 & 0.000000 & 1.13 & 0.352 \\
Residual Log-Lactate & 3 & 0.02836 & 0.68 & 0.573
\end{tabular}

Residual $\mathrm{MO}_{2}$, ATP and $\log _{10}$-Lactate of Thysanoessa inermis tested against $\mathrm{pH}$ as a fixed factor

$d f$ degrees of freedom, Adj. $M S$ adjusted mean of squares, $F \mathrm{~F}$ ratio, $p$ probability level

$87.8,90,81.1$, and $87.8 \%$ on day 3 and $62.2,60,63.3$ and $57.8 \%$ on day 7 for $\mathrm{pH}$ treatments $8.06,7.79,7.65$ and 7.38 , respectively.

\section{Discussion}

To our knowledge, this study is the first to examine the short-term biological responses of overwintering Arctic krill to ocean acidification (OA) in relation to natural conditions found in Arctic fjord seawater chemistry. Overall, we found no significant physiological impacts of $\mathrm{OA}$ on overwintering individuals of $T$. inermis from the Arctic fjord of Kongsfjord.

Global change has the potential to impact Kongsfjord in a number of ways. In the outer fjord there will be a large influence from changing oceanographic conditions, such as an increased penetration of warmer, more saline Atlantic water (Willis et al. 2006); while the inner fjord could be exposed to increased river run-off and melt from the large tidal glaciers (Svendsen et al. 2002). Similar to previous studies carried out in April (Cottier et al. 2005; Willis et al. 2006), the presence of a warmer, more saline, well-mixed water column throughout most of Kongsfjord, with a stratified water column of colder fresher water in the inner fjord, indicates a large influence of Atlantic water (AW), or modified-Atlantic water (MAW) within the fjord. The stratified inner fjord could be the remains of trapped Arctic water as well as an input of fresh meltwater.

The carbonate chemistry data presented here are comparable to previously reported results from within Kongsfjord. Total alkalinity (TA) measured between 200 and $300 \mathrm{~m}$ depth has been reported to range from 2295 to $2334 \mu \mathrm{mol} \mathrm{kg}{ }^{-1}$. Additionally, $\mathrm{pH}$ recorded at this depth ranged from 8.13 to 7.68 , whereas $p \mathrm{CO}_{2}$ ranged from a low of 309-979 $\mu \mathrm{atm}$ (Lischka and Riebesell 2012). This data is also comparable to those from the MAW and AW masses in the Fram Strait, located between Greenland and Svalbard, for TA $\left(2297 \pm 5\right.$ and $2325 \pm 7 \mu \mathrm{mol} \mathrm{kg}^{-1}$, respectively) and dissolved inorganic carbon (DIC: $2148 \pm 5$ and $2120 \pm 20 \mu \mathrm{mol} \mathrm{kg}{ }^{-1}$, respectively) (Anderson et al. 1998; Jeansson et al. 2011). Total alkalinity was lowest at the stations near the glacial front, and highest in the outer fjord, suggesting a freshwater dilution of TA. In contrast, DIC was highest near the glacier front likely because of remineralisation of organic matter releasing $\mathrm{CO}_{2}$ and thus increasing DIC, as a result of movements of glaciers or icebergs stirring up organic matter (Feely et al. 2010). The benthic organic matter in Kongsfjord is regulated singularly by zooplankton grazing (Hop et al. 2002). $\mathrm{CO}_{2}$ released during respiratory remineralisation causes a decrease in $\mathrm{pH}$ (Shadwick et al. 2013), which is evidenced here in the inner fjord with an area of lower $\mathrm{pH}$ and higher $p \mathrm{CO}_{2}$. Changes in water mass dominance, Arctic versus Atlantic, are a usual occurrence in Kongsfjord and are most likely to influence the pelagic system (Hop et al. 2002). Zooplankton like $T$. inermis are advected to the glacial front where they are exposed to fresh meltwater and subsequent low pH (Hop et al. 2002) and shifts in zooplankton community composition have been linked to water mass advection in Kongsfjord (Willis et al. 2006).

With respect to OA, an organisms' habitat and consequent exposure to a range of $p \mathrm{CO}_{2}$ conditions has been shown to lead to a greater tolerance to such stress (Watanabe et al. 2006; Maas et al. 2012; Calosi et al. 2013a; Lewis et al. 2013; Pespeni et al. 2013; Lucey et al. 2015). Specifically, this has also been observed in crustaceans that are regularly exposed to variable environmental conditions through behaviour and life history characteristics (Watanabe et al. 2006; Lewis et al. 2013), as well as physiological adaptation (Turner et al. 2016). In detail, deep-living copepods from the subarctic North Pacific were found to be more tolerant to high $p \mathrm{CO}_{2}$ than their sub-tropical counterparts, which could be attributed to variable $p \mathrm{CO}_{2}$ conditions in the subarctic ocean (Watanabe et al. 2006). Adult Calanus spp. in the high Canadian Arctic exposed to a range of $p \mathrm{CO}_{2}$ conditions during daily vertical migrations were less sensitive to high $p \mathrm{CO}_{2}$ conditions than surface water dwelling $O$. similis (Lewis et al. 2013). Our work further corroborates this, as we show that low $\mathrm{pH}$ does not significantly affect $T$. inermis' physiology when considering individuals' metabolic rates and metabolite concentrations. This tolerance to low $\mathrm{pH}$ could be due to either phenotypic plasticity or adaptation to the naturally variable $\mathrm{pH}$ found within the fjord.

Metabolic activity for $T$. inermis reported in our study are comparable to mean respiration rates reported for T. inermis collected in Hornsund (Svalbard, Norway) and incubated at similar temperatures $\left(4{ }^{\circ} \mathrm{C}\right)$ (Huenerlage and Buchholz 2015). In addition, T. inermis metabolic activity is similar but slightly lower than those previously reported for the krill Meganyctiphanes norvegica $\left(19.9-92.9 \mu \mathrm{mol} \mathrm{O} \mathrm{O}_{2} \mathrm{~g}^{-1} \mathrm{~h}^{-1}\right.$ 
DW) at ambient pH and comparable temperatures (Mayzaud 1973; Sameoto 1976; Båmstedt 1979; Hirche 1984; Saborowski et al. 2002). Thysanoessa inermis metabolic rate might be expected to be slightly lower than that of $M$. norvegica due to interspecific differences as well as geographic location, $T$. inermis is found living in overall colder habitats (Clarke and Peck 1991; Clarke 1998). In addition, total lipid percentages for $M$. norvegica, span 20-50\% of their dry mass in the Fram Strait with $T$. inermis in Kongsfjord within that range but slightly lower at $21-42 \%$ dry mass (Falk-Petersen et al. 2000). The similar metabolic rate compared to other studies suggests that the krill in our experiments were not unduly stressed by handling prior to incubation or the relatively short-term incubation we employed in our study. Mean metabolic rate was comparable across all $\mathrm{pH}$ treatments, indicating that krill exposed to low $\mathrm{pH}$ for a short time period (7 days) were able to maintain metabolic rates comparable to those previously reported for animals in ambient $\mathrm{pH}$ seawater. Daily and seasonal variability (AWIPEV Underwater Observatory (only monitors surface waters, node located at $11 \mathrm{~m}$ depth), https://cosyna-nodes.shinyapps.io/svl_ferry box/) of fjord carbonate chemistry in combination with the migratory behaviour of $T$. inermis could provide them with a pre-exposure that has given the species an advantage to cope with changes in environmental $\mathrm{pH}$. The ability to maintain metabolic rates at low $\mathrm{pH}(7.95,7.80,7.61)$ has been observed in other species, including the Arctic copepod Pseudocalanus acuspes from Kongsfjord, although the combination of low $\mathrm{pH}$ and prey concentration affected metabolic rates significantly (Thor and Oliva 2015). Additionally, exposure to elevated $p \mathrm{CO}_{2}$ over a 2 month period had no detrimental effects on the oxygen consumption rate of early life stages of the Arctic copepod, C. glacialis (Bailey et al. 2017). The ability to maintain metabolic rates at low $\mathrm{pH}$ has been observed in non-Arctic species, like the deep-sea pteropods of the Pacific, which migrate into elevated $p \mathrm{CO}_{2}$ oxygen minimum zones (Maas et al. 2012).

The ATP concentrations observed here were lower than values previously reported for $M$. norvegica (Skjoldal and Båmstedt 1977; Ventura 2006). This difference could be due to interspecific differences, as well as differences in methodology and the timing of our sampling: i.e. we sampled krill prior to the onset of the spring bloom, as herbivorous species these krill will reach peak ATP levels during the spring bloom (Skjoldal and Båmstedt 1977). Importantly, the mean ATP concentrations reported here show that there was very little energy commitment being made by $T$. inermis during this time, potentially an indication of their overwintering state.

Like metabolic rate, mean ATP concentration and mean L-lactate L-lactate concentration were also consistent across $\mathrm{pH}$ treatments, indicating that the krill are able to maintain aerobic metabolism and that energy metabolism was not compromised at different $\mathrm{pH}$ levels, i.e. maintenance of metabolic rates came at no apparent energetic cost as there was no observable differences in ATP concentration or evidence supporting an increase in anaerobic metabolism. In contrast, Antarctic krill, E. superba, exposed to elevated $p \mathrm{CO}_{2}(672 \mu \mathrm{atm})$ conditions for just $24 \mathrm{~h}$, showed an increase in nutrient release rates and metabolic activity that are associated with the maintenance of internal acid-base equilibrium (Saba et al. 2012). One explanation for these different responses is the different length of experimental exposure between our study (7 days) and that of Saba et al. (2012) (24 h). The metabolic response, and subsequent increased ingestion found by Saba et al. (2012) could plausibly be that responses recorded following a short-term exposure (several hours) to low $\mathrm{pH} /$ elevated $\mathrm{pCO}_{2}$ are not maintained over a longer period of exposure (i.e. several days as tested here or weeks to months), as shown by Sperfeld et al. (2014) and Suckling et al. (2015). Long-term metabolic rate adjustments in response to low $\mathrm{pH}$ and increased temperature were observed in the Antarctic sea urchin, Sterechinus neumayeri, where adults took 6-8 months to acclimatise to experimental conditions but showed no measurable effect of low $\mathrm{pH}$ and increased temperature on metabolic rates after this period (Suckling et al. 2015). Indeed Sperfeld et al. (2014) exposed Nyctiphanes couchii, a Northern Atlantic krill species, to elevated $\mathrm{CO}_{2}$ conditions for 5 weeks, and found no consistent detrimental impacts of near future elevated $p \mathrm{CO}_{2}$ $(<1100 \mu \mathrm{atm})$ on growth or their exoskeleton, although survival decreased and the frequency of moult-related deaths increased above $1100 \mu \mathrm{atm}$.

Furthermore, it is also important to consider that the susceptibility to OA may be associated with differences in lifestyle, life history stage, as well as the ability to compensate for changes in the environment (Whiteley 2011). For instance, krill embryonic development and larvae were found to become impacted by $p \mathrm{CO}_{2}$ elevated above 1000 $\mu$ atm (Kawaguchi et al. 2011, 2013), and gravid females were found to be more sensitive to elevated $\mathrm{CO}_{2}$ than nongravid krill (Saba et al. 2012), while the sub-adults from Sperfeld et al. (2014) and adults in this study suggest that these stages are potentially more tolerant to elevated $\mathrm{CO}_{2}$.

Our findings suggest that exposure to natural gradients in seawater chemistry $\left(\mathrm{pH}, p \mathrm{CO}_{2}\right)$ has resulted in the ability to tolerate at least short-term exposure to low $\mathrm{pH}$ in overwintering individuals of $T$. inermis. Nonetheless, limited food availability during the winter months along with a potential demand for more food to compensate for the negative effects of low $\mathrm{pH}$ could still represent a challenge for Arctic krill in the future. Furthermore, warming, along with acidification, poses a serious threat to Arctic ecosystems, and hence future work should also include $T$. 
inermis's response to multiple stressors. Future OA studies at high latitudes should consider conducting long-term exposure to low $\mathrm{pH} /$ elevated $\mathrm{pCO}_{2}$ (Rodríguez-Romero et al. 2015; Thor and Dupont 2015; Suckling et al. 2015; Lucey et al. 2016). However, logistics and a short field season might present a problem in conducting longer-term experiments.

Acknowledgments This work was part of the project "Ocean Acidification in Arctic Fjords" funded by IUCN Polar Programme, through financial support from Biotherm. P.C. is supported by the Natural Sciences and Engineering Research Council of Canada and the FRQ-NT New University Researchers Start Up Program. We thank J. A. Moody (Plymouth University) for his assistance with the biochemical assay procedures. We also thank the staff at Kings Bay, Ny-Ålesund and N. Cox (NERC Arctic base manager) for their support while in the field. Thank you to R.E. Burnham and J. F. Dower (University of Victoria) and the anonymous reviewers for their comments.

\section{References}

Agersted MD, Nielsen TG, Munk P et al (2011) The functional biology and trophic role of krill (Thysanoessa raschii) in a Greenlandic fjord. Mar Biol 158:1387-1402. doi:10.1007/ s00227-011-1657-z

Aguilera VM, Vargas CA, Manriquez PH et al (2013) Low-pH freshwater discharges drive spatial and temporal variations in life history traits of neritic copepod Acartia tonsa. Estuar Coasts 36:1084-1092. doi:10.1007/s12237-013-9615-2

Anderson LG, Olsson K, Chierici M (1998) A carbon budget for the Arctic Ocean. Glob Biogeochem Cycles 12:455-465

Azetsu-Scott K, Clarke A, Falkner K et al (2010) Calcium carbonate saturation states in the waters of the Canadian Arctic Archipelago and the Labrador Sea. J Geophys Res Ocean. doi:10.1029/2009JC005917

Bailey A, Thor P, Browman HI et al (2017) Early life stages of the Arctic copepod Calanus glacialis are unaffected by increased seawater $\mathrm{pCO}_{2}$. ICES J Mar Sci 74:996-1004

Båmstedt U (1979) Seasonal variation in the respiratory rate and ETS activity of deep-water zooplankton from the Swedish west coast. Cyclic Phenomena in Marine Plants and Animals. Pergamon Press, Oxford, pp 267-274

Bates NR, Mathis JT, Cooper LW (2009) Ocean acidification and biologically induced seasonality of carbonate mineral saturation states in the western Arctic Ocean. J Geophys Res Ocean 114:1-21. doi:10.1029/2008JC004862

Bennett AF (1987) Interindividual variability: an underutilized resource. New Dir Ecol Physiol. doi:10.1002/mus.880150105

Boden BP, Johnson MW, Brinton E (1955) The Euphausiacea (Crustacea) of the North Pacific, vol 6. University of California Press, Berkeley, pp 287-400

Buchholz F, Buchholz C, Weslawski JM (2010) Ten years after: Krill as indicator of changes in the macro-zooplankton communities of two Arctic fjords. Polar Biol 33:101-113. doi:10.1007/ s00300-009-0688-0

Caldeira K, Wickett ME (2003) Oceanography: anthropogenic carbon and ocean pH. Nature 425:365. doi:10.1038/425365a

Calosi P, Rastrick SPS, Graziano M et al (2013a) Distribution of sea urchins living near shallow water $\mathrm{CO}_{2}$ vents is dependent upon species acid-base and ion-regulatory abilities. Mar Pollut Bull 73:470-484. doi:10.1016/j.marpolbul.2012.11.040
Calosi P, Rastrick SPS, Lombardi C et al (2013b) Adaptation and acclimatization to ocean acidification in marine ectotherms: an in situ transplant experiment with polychaetes at a shallow $\mathrm{CO} 2$ vent system. Philos Trans R Soc B Biol Sci 368:20120444. doi:10.1098/rstb.2012.0444

Calosi P, Turner LM, Hawkins M et al (2013c) Multiple physiological responses to multiple environmental challenges: an individual approach. Integr Comp Biol 53:660-670. doi:10.1093/icb/ict041

Christen N, Calosi P, McNeill CL, Widdicombe S (2013) Structural and functional vulnerability to elevated $\mathrm{pCO}_{2}$ in marine benthic communities. Mar Biol 160:2113-2128. doi:10.1007/s00227012-2097-0

Clarke A (1998) Temperature and energetics: an introduction to cold ocean physiology. In: Portner H-O, Playle RC (eds) Cold ocean physiology. Cambridge University Press, Cambridge, pp 3-32

Clarke A, Peck LS (1991) The physiology of polar marine zooplankton. Polar Res 10:355-370. doi:10.1111/j.1751-8369. 1991.tb00659.x

Comeau S, Alliouane S, Gattuso JP (2012) Effects of ocean acidification on overwintering juvenile Arctic pteropods Limacina helicina. Mar Ecol Prog Ser 456:279-284. doi:10.3354/ meps09696

Cottier F, Tverberg V, Inall M et al (2005) Water mass modification in an Arctic fjord through cross-shelf exchange: the seasonal hydrography of Kongsfjorden, Svalbard. J Geophys Res Ocean 110:1-18. doi:10.1029/2004JC002757

Dahl TM, Falk-Petersen S, Gabrielsen GW et al (2003) Lipids and stable isotopes in common eider, black-legged kittiwake and northern fulmar: atrophic study from an Arctic fjord. Mar Ecol Prog Ser 256:257-269. doi:10.3354/meps256257

Dalpadado P, Yamaguchi A, Ellertsen B, Johannessen S (2008) Trophic interactions of macrozooplankton (krill and amphipods) in the Marginal Ice Zone of the Barents Sea. Deep Res Part II Top Stud Oceanogr 55:2266-2274. doi:10.1016/j.dsr2.2008.05. 016

Dickson AG, Millero FJ (1987) A comparison of the equilibrium constants for the dissociation of carbonic acid in seawater media. Deep Sea Res Part A 34:1733-1743. doi:10.1016/01980149(87)90021-5

Dickson AG, Sabine CL, Christian JR (2007) Guide to best practices for ocean $\mathrm{CO}_{2}$ measurements. PICES Spec Publ 3(3):191. doi:10.1159/000331784

Donohue PJC, Calosi P, Bates AH et al (2012) Impact of exposure to elevated $\mathrm{pCO}_{2}$ on the physiology and behaviour of an important ecosystem engineer, the burrowing shrimp Upogebia deltaura. Aquat Biol 15:73-86. doi:10.3354/ab00408

Dupont S, Pörtner HO (2013) A snapshot of ocean acidification research. Mar Biol 160:1765-1771. doi:10.1007/s00227-0132282-9

Fabry V, Seibel B, Feely RA, Orr JC (2008) Impacts of ocean acidification on marine fauna and ecosystem processes. ICES J 65:414-432

Fabry V, McClintock J, Mathis J, Grebmeier J (2009) Ocean acidification at high latitudes: the bellwether. Oceanography 22:160-171. doi:10.5670/oceanog.2009.105

Falk-Petersen S, Hagen W, Kattner G et al (2000) Lipids, trophic relationships, and biodiversity in Arctic and Antarctic krill. Can J Fish Aquat Sci 57:178-191. doi:10.1139/f00-194

Feely RA, Alin SR, Newton J et al (2010) The combined effects of ocean acidification, mixing, and respiration on $\mathrm{pH}$ and carbonate saturation in an urbanized estuary. Estuar Coast Shelf Sci 88:442-449. doi:10.1016/j.ecss.2010.05.004

Findlay HS, Kendall MA, Spicer JI, Widdicombe S (2010) Relative influences of ocean acidification and temperature on intertidal barnacle post-larvae at the northern edge of their geographic 
distribution. Estuar Coast Shelf Sci 86:675-682. doi:10.1016/j. ecss.2009.11.036

Hirche HJ (1984) Temperature and metabolism of plankton-I. Respiration of antarctic zooplankton at different temperatures with a comparison of antarctic and nordic krill. Comp Biochem Physiol Part A 77:361-368. doi:10.1016/0300-9629(84)90074-4

Hop H, Pearson T, Hegseth EN et al (2002) The marine ecosystem of Kongsfjorden, Svalbard. Polar Res 21:167-208

Hop H, Falk-Petersen S, Svendsen H et al (2006) Physical and biological characteristics of the pelagic system across Fram Strait to Kongsfjorden. Prog Oceanogr 71:182-231. doi:10.1016/ j.pocean.2006.09.007

Huenerlage K, Buchholz F (2015) Thermal limits of krill species from the high-Arctic Kongsfjord (Spitsbergen). Mar Ecol Prog Ser 535:89-98. doi:10.3354/meps11408

Jeansson E, Olsen A, Eldevik T et al (2011) The Nordic Seas carbon budget: sources, sinks, and uncertainties. Glob Biogeochem Cycles 25:1-16. doi:10.1029/2010GB003961

Kathman RD, Austin WC, Saltman JC, Fulton JD (1986) Identification manual to the Mysidacea and Euphausiacea of the Northeast Pacific. Can Spec Publ Fish Aquat Sci 93:411. doi:10.1017/ CBO9781107415324.004

Kawaguchi S, Kurihara H, King R et al (2011) Will krill fare well under Southern Ocean acidification? Biol Lett 7:288-291. doi:10.1098/rsbl.2010.0777

Kawaguchi S, Ishida A, King R et al (2013) Risk maps for Antarctic krill under projected Southern Ocean acidification. Nat Clim Chang 3:843-847. doi:10.1038/nclimate1937

Lewis E, Wallace D (1998) Program developed for $\mathrm{CO}_{2}$ system calculations. Ornl/Cdiac-105 1-21

Lewis CN, Brown KA, Edwards LA et al (2013) Sensitivity to ocean acidification parallels natural $\mathrm{pCO}_{2}$ gradients experienced by Arctic copepods under winter sea ice. Proc Natl Acad Sci 110:E4960-E4967. doi:10.1073/pnas.1315162110

Lischka S, Riebesell U (2012) Synergistic effects of ocean acidification and warming on overwintering pteropods in the Arctic. Glob Chang Biol 18:3517-3528. doi:10.1111/gcb.12020

Lucey NM, Lombardi C, DeMarchi L et al (2015) To brood or not to brood: are marine invertebrates that protect their offspring more resilient to ocean acidification? Sci Rep 5:12009. doi:10.1038/ srep12009

Lucey NM, Lombardi C, Florio M et al (2016) An in situ assessment of local adaptation in a calcifying polychaete from a shallow $\mathrm{CO}_{2}$ vent system. Evol Appl 9:1054-1071

Lundin A (2000) Use of firefly luciferase in ATP-related assays of biomass, enzymes, and metabolites. Methods Enzymol 305:346-370

Maas AE, Wishner KF, Seibel BA (2012) The metabolic response of pteropods to acidification reflects natural $\mathrm{CO}_{2}$-exposure in oxygen minimum zones. Biogeosciences 9:747-757. doi:10. 5194/bg-9-747-2012

Mauchline J (1980) The biology of mysids and euphausiids. JHS Blaxter, FS Russell, M Yonge (eds) Part two, the biology of euphausiids, vol 18. Advances in Marine Biology. Academic Press, London, pp 373-681

Mayzaud P (1973) Respiration et Excrétion azotée du zooplancton. III. Etude de l'influence des variations thermiques. Ann Inst Ocean 49:113-122

Mehrbach C, Culberson CH, Hawley JE, Pytkowicx RM (1973) Measurement of the apparent dissociation constants of carbonic acid in seawater at atmospheric pressure. Limnol Oceanogr 18:897-907. doi:10.4319/lo.1973.18.6.0897

Melatunan S, Calosi P, Rundle SD et al (2011) Exposure to elevated temperature and $\mathrm{PCO}_{2}$ reduces respiration rate and energy status in the periwinkle Littorina littorea. Physiol Biochem Zool 84:583-594. doi:10.1086/662680
Nemoto T (1966) Thysanoessa eupahusiids, comparative morphology, allomorphosis and ecology. Sci Rep Whales Res Inst 20:109-155

Niehoff B, Schmithüsen T, Knüppel N et al (2013) Mesozooplankton community development at elevated $\mathrm{CO}_{2}$ concentrations: results from a mesocosm experiment in an Arctic fjord. Biogeosciences 10:1391-1406. doi:10.5194/bg-10-1391-2013

Pespeni MH, Chan F, Menge BA, Palumbi SR (2013) Signs of adaptation to local $\mathrm{pH}$ conditions across an environmental mosaic in the california current ecosystem. Integr Comp Biol 53:857-870. doi:10.1093/icb/ict094

Pinchuk AI, Hopcroft RR (2006) Egg production and early development of Thysanoessa inermis and Euphausia pacifica (Crustacea: Euphausiacea) in the northern Gulf of Alaska. J Exp Mar Biol Ecol 332:206-215. doi:10.1016/j.jembe.2005.11.019

Pörtner HO, Peck L, Zielinski S, Conway LZ (1999) Intracellular pH and energy metabolism in the highly stenothermal Antarctic bivalve Limopsis marionensis as a function of ambient temperature. Polar Biol 22:17-30. doi:10.1007/s003000050386

Riebesell U, Gattuso JPP, Thingstad TFF, Middelburg JJJ (2013) Arctic ocean acidification: pelagic ecosystem and biogeochemical Dynamics responses during a mesocosm study. Biogeosciences 10:5619-5626. doi:10.1594/PANGAEA.769833

Rodríguez-Romero A, Jarrold MD, Massamba-N'Siala G et al (2015) Multi-generational responses of a marine polychaete to a rapid change in seawater pCO2. Evol Appl. doi:10.1111/eva.12344

Saba GK, Schofield O, Torres JJ et al (2012) Increased feeding and nutrient excretion of adult Antarctic Krill, Euphausia superba, exposed to enhanced carbon dioxide $\left(\mathrm{CO}_{2}\right)$. PLoS ONE 7:1-12. doi:10.1371/journal.pone.0052224

Saborowski R, Brohl S, Tarling GA, Buchholz F (2002) Metabolic properties of Northern krill, Meganyctiphanes norvegica, from different climatic zones. I. Respiration and excretion. Mar Biol 140:547-556. doi:10.1007/s00227-001-0730-4

Sameoto DD (1976) Respiration rates, energy budgets, and molting frequencies of three species of Euphausiids found in the Gulf of St. Lawrence. J Fish Res Board Can 33:2568-2576. doi:10.1139/ f76-301

Sargent JR, Falk-Petersen S (1981) Ecological investigations on the zooplankton community in balsfjorden, northern Norway: lipids and fatty acids in Meganyctiphanes norvegica, Thysanoessa raschi and T. inermis during mid-winter. Mar Biol 62:131-137. doi:10.1007/BF00388175

Shadwick EH, Trull TW, Thomas H, Gibson JAE (2013) Vulnerability of polar oceans to anthropogenic acidification: comparison of Arctic and Antarctic seasonal cycles. Sci Rep 3:2339. doi:10. 1038/srep02339

Skjoldal HR, Båmstedt U (1977) Ecobiochemical studies on the deepwater pelagic community of Korsfjorden, Western Norway. Adenine nucleotides in zooplankton. Mar Biol 42:197-211

Somero GN (2002) Thermal physiology and vertical zonation of intertidal animals: optima, limits, and costs of living. Integr Comp Biol 42:780-789. doi:10.1093/icb/42.4.780

Sperfeld E, Mangor-Jensen A, Dalpadado P (2014) Effect of increasing sea water $\mathrm{pCO}_{2}$ on the northern Atlantic krill species Nyctiphanes couchii. Mar Biol 161:2359-2370. doi:10.1007/ s00227-014-2511-x

Steinacher M, Joos F, Frölicher TL et al (2009) Imminent ocean acidification in the Arctic projected with the NCAR global coupled carbon cycle-climate model. Biogeosciences 6:515-533. doi:10.5194/bg-6-515-2009

Storch D, Santelices P, Barria J et al (2009) Thermal tolerance of crustacean larvae (zoea I) in two different populations of the kelp crab Taliepus dentatus (Milne-Edwards). J Exp Biol 212:1371-1376. doi:10.1242/jeb.030205 
Suckling CC, Clark MS, Richard J et al (2015) Adult acclimation to combined temperature and $\mathrm{pH}$ stressors significantly enhances reproductive outcomes compared to short-term exposures. J Anim Ecol 84:773-784. doi:10.1111/1365-2656.12316

Svendsen H, Beszczynska-Møller A, Hagen JO et al (2002) The physical environment of Kongsfjorden-Krossfjorden, an Arctic fjord system in Svalbard. Polar Res 21:133-166. doi:10.1111/j. 1751-8369.2002.tb00072.x

Terai H, Hannouche D, Ochoa E et al (2002) In vitro engineering of bone using a rotational oxygen-permeable bioreactor system. Mater Sci Eng C 20:3-8. doi:10.1016/S0928-4931(02)00006-1

Thor P, Dupont S (2015) Transgenerational effects alleviate severe fecundity loss during ocean acidification in a ubiquitous planktonic copepod. Glob Chang Biol 21:2261-2271. doi:10. $1111 / \mathrm{gcb} .12815$

Thor P, Oliva EO (2015) Ocean acidification elicits different energetic responses in an Arctic and a boreal population of the copepod Pseudocalanus acuspes. Mar Biol 162:799-807. doi:10. 1007/s00227-015-2625-9

Turner LM, Ricevuto E, Massa Gallucci A et al (2016) Metabolic responses to high $\mathrm{pCO}_{2}$ conditions at a $\mathrm{CO}_{2}$ vent site in juveniles of a marine isopod species assemblage. Mar Biol 163:1-11. doi:10.1007/s00227-016-2984-x

Ventura M (2006) Linking biochemical and elemental composition in freshwater and marine crustacean zooplankton. Mar Ecol Prog Ser 327:233-246

Watanabe Y, Yamaguchi A, Ishida H et al (2006) Lethality of increasing $\mathrm{CO}_{2}$ levels on deep-sea copepods in the western North Pacific. J Oceanogr 62:185-196. doi:10.1007/s10872-006-0043-9

Weslawski JM, Ryg M, Smith TG, Oritsland NA (1994) Diet of ringed seals (Phoca hispida) in a fjord of west Svalbard. Arctic 47:109-114

Weslawski JM, Pedersen G, Petersen SF, Poraziński K (2000) Entrapment of macroplankton in an Arctic fjord basin, Kongsfjorden, Svalbard. Oceanologia 42:57-69

Whiteley NM (2011) Physiological and ecological responses of crustaceans to ocean acidification. Mar Ecol Prog Ser 430:257-271. doi:10.3354/meps09185

Willis K, Cottier F, Kwasniewski S et al (2006) The influence of advection on zooplankton community composition in an Arctic fjord (Kongsfjorden, Svalbard). J Mar Syst 61:39-54. doi:10. 1016/j.jmarsys.2005.11.013 